\title{
Implementation of enterprise human resources management standards to achieve supply chain excellence in fertilizer companies in Indonesia
}

\author{
Noer Soetjipto $^{a^{*}}$, Sulastri Sulastri ${ }^{a}$, Juli Prastyorini ${ }^{b}$, Soedarmanto Soedarmanto ${ }^{b}$ and Ari \\ Riswanto
}

${ }^{a}$ Sekolah Tinggi Ilmu Ekonomi YAPAN Surabaya, Indonesia

${ }^{b}$ Sekolah Tinggi Ilmu Administrasi dan Manajemen Kepelabuhan (STIAMAK) Barunawati Surabaya, Indonesia 'STKIP PGRI Sukabumi, Indonesia

\begin{tabular}{l}
\hline C H R O N I C L E \\
\hline Article history: \\
Received September 2, 2020 \\
Received in revised format \\
October 18,2020 \\
Accepted November 142020 \\
Available online \\
November 142020 \\
\hline Keywords: \\
Enterprise standards \\
Human resources \\
management \\
Supply chain \\
Company excellence
\end{tabular}

\section{A B S T R A C T}

Employees have collective skills, abilities and experience that contribute to the interests of the company where they work, and can contribute to the success of supply chain and is a resource that is an asset in achieving supply chain excellence. To examine this relationship, this study investigates the role of human resources management (HRM) on the supply chain management of fertilizer companies in Indonesia, which is focused on the distribution and logistics of fertilizer from producer to their network and consumers. This study took samples from two fertilizer companies in East Java, structural equation modeling (SEM) analysis was carried out with the Smart PLS. 18 (Partial Least Square) program, and shows the value of $\mathrm{t}=348.825$ with $\mathrm{p}=0.000$ $(p<0.000)$ which means there is a significant effect of implementing enterprise human resources management (HRM) standards on company supply chain excellence and represents indicators of management strategy, cost leadership, focus on productivity, logistics, distributions, operational effectiveness, differentiation, and cooperation with companies or other institutions that support each other. The results of this study have provided an overview of the application of enterprise capable of supporting human resource management. Enterprise standards in both fertilizer companies are applied regularly, starting from checking the completeness of the employee database, including contact information, details of salary, compensation and benefits; attendance, employee performance, career planning, work relations, socialization, and informal communication so that the company would be able to adapt and be more flexible towards every need in the present and in the future.

\section{Introduction}

Theoretical conceptualization broadly confirms that there are many ways to gain advantage, but basically there are two types of cost advantage and differentiation advantage. A company that is able to achieve a supply chain advantage in cost or differentiation is able to offer consumers a product at a lower cost or with a higher level of differentiation and most importantly, able to compete with its competitors (Mughal, 2019). An organization that is able to outperform its competitors over a long period of time has a sustainable competitive advantage. In addition, the skills of employees in the marketing, production, distribution, and quality control departments must also be integrated with each other and be able to build relationships with consumers and other employees as interrelated work relations in the form of good relationships, so that a strong value chain will be established between companies and employees, the impact of which is the formation of trust and good impressions from customer relationship (Wibowo et al., 2020). For this reason, the application of enterprise HRM is urgent and very necessary as a corporate work system and HR management on all lines. HRM facilitates employees to

* Corresponding author

E-mail address: noersoetjipto.stieyapan@gmail.com (N. Soetjipto)

C 2021 by the authors; licensee Growing Science. doi: $10.5267 /$ j.uscm.2020.11.004 
achieve company goals. Broadly speaking, HRM according to several theories, such as those proposed by Rainer and Cegielski, (2012), is a strategy or series of steps and approaches to manage or use human resources (HR) to achieve goals/goals set by the company/organization.

Human resource management (HR) is a management that focuses its attention on human production factors with all its activities to achieve company goals. Human resource is an investment that plays an important role for the company. Without human resources, other production factors cannot be maximized to achieve company goals. Monk and Wagner (2012), explain that the main objective in implementing enterprise HRM is to ensure that companies can achieve success or excellence through the work abilities of employees (Ali et al., 2012). The company's supply chain advantage is the competitive advantage when the company does business better than its competitors. The firm makes higher than average returns for all firms in the industry. For a business, supply chain excellence is the main goal. Without it, companies will find it difficult to survive profitably, and they always try to maintain this advantage. Porter (1997) explains that company advantage that leads to competitive ability is not permanent or can change due to changes in the business environment. When a business cannot adapt and change its strategy, competitors can seize it. For that the company's excellence remains in its ability to compete and outperform competitors. This speed will determine how long the company will last. Competitors can acquire the skills needed to compete effectively, and can duplicate the benefits of a firm's value creation strategy beyond what already exists. Focusing on competitive advantage of supply chain can be done by means of operational effectiveness. Operational effectiveness supply chain when combined with the right strategy is the way to achieve superior performance. By maximizing these advantages, the expected competitive advantage will be achieved. This can be done through the use of inputs, for example by reducing defects in the product or making a faster and higher quality product. This study aims to determine the impact of the application of enterprise human resources management (HRM) on the supply chain excellence of company in fertilizer trading competition, which emphasizes aspects of human resource management or employees. Fertilizer production to this day is still relatively dependent on government policy, because almost all fertilizer producers are SOEs (State-Owned Enterprises), whose main production objective is to support agricultural and plantation activities in Indonesia. In addition to production that refers to domestic needs, the development of fertilizer production is also constrained by the supply of gas as a raw material for fertilizer, especially the type of urea fertilizer to meet the needs of the fertilizer industry. Given the strategic role of fertilizers, the provision of fertilizers along with its crucial role of supply chain at prices affordable to farmers is a critical problem, especially when the government issues a policy to eliminate fertilizer subsidies, and the price of fertilizers cannot be completely left to the market mechanism because of the fertilizer prices that have been used by farmers for rice, soybean and corn plantations are less affordable for farmers. This study aims to investigate the market mechanism encouragement of fertilizer companies in Indonesia, especially in the form of SOEs to have the supply chain advantage to make the price affordable, and the products always available in the market, to successfully compete in the market by maximizing their HRM to obtain competitive advantage.

\section{Literature review}

\subsection{Company Excellence and Crucial Role of supply chain in Fertilizer Companies}

The theory of company advantage is a form of company management's ability to manage all potential resources, especially its human resources to be able to perform better than others in the company, in the same industry and market. This theory was put forward by Porter (1985) as a form of citicism of the theory of comparative advantage. Porter (1985) explains that one of the strategies to win the competition is to have a competitive advantage. This opinion is further strengthened by the opinion of Day and Wensley (1988), the excellence of the company is the ability to compete in a sustainable manner as a form of strategy for business actors in maintaining the survival of their company. Furthermore, Fernaldi (2016) states that in a competitive market, and the ability of economic actors to produce performance, especially performance in the financial sector, this is highly dependent on the degree of competitiveness as the export theory according to experts. Economic actors who are said to have a competitive advantage in managing a company are people who have something that competitors do not have, and can do something or prove a better product.

Focusing on achieving corporate excellence and supply chain advantage in competition can be done by increasing operational effectiveness. Effective operations are combined with the right strategy as a way to achieve superior performance (Porter, 1980). So, by maximizing these advantages, the expected competitive advantage will be achieved. In supply chain analysis, operational effectiveness helps companies show something that can be good from competitors. This can be done through the use of inputs, for example by reducing product defects or making the product faster and highly available in the market. According to Herman (2018), explaining competitive advantage is a study of the differences and uniqueness among competitors. According to Day and Wensley (1988), Pepall et al. (2005), competitive advantage is different competitions in terms of excellence in expertise and resources. The source of competitive advantage is superior skills, resources and control, as seen in Fig. 1. 


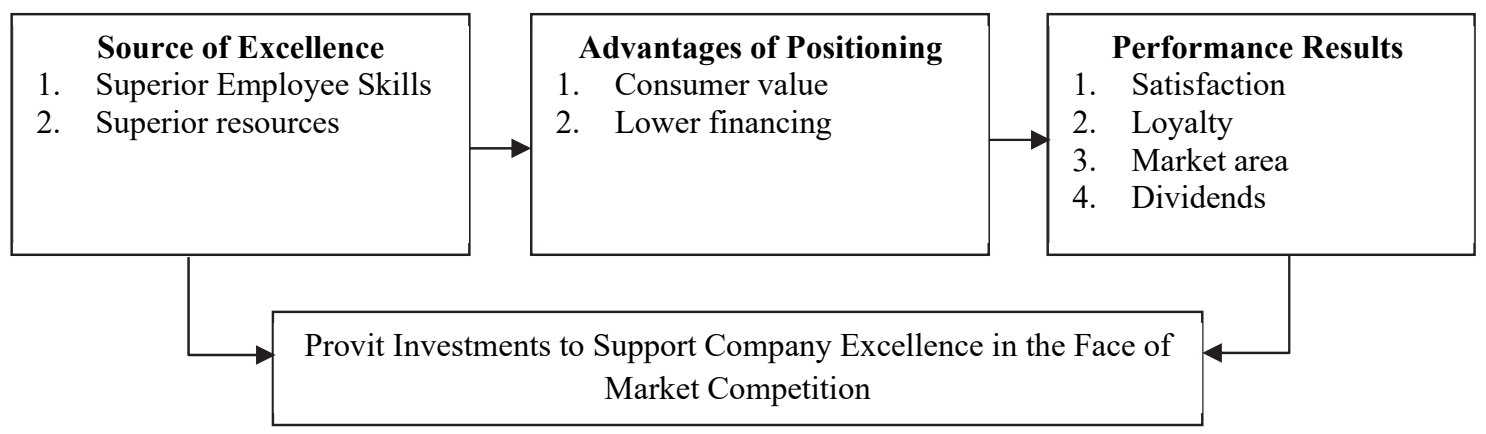

Fig. 1. Elements of Corporate Excellence

\subsection{Enterprise Human Resources Management and Supply Chain Excellence}

Human characteristics are inherently difficult to understand, difficult to manage, let alone measure. In fact, human resources are the most powerful and mysterious asset of a company. Therefore, the HR sector tries to measure human resources by linking people with strategy and performance to produce company excellence and be able to describe the mission, vision and strategy. Describe a relationship of cause (leading/intangible) and effect (lagging/tangible), the key is to be able to describe humans with all their potentials and on the other hand there is a contribution that can be made in achieving company goals. Pepall et al. (2005), describe the enterprise as a system of people, equipment, material, data, policies and procedures that appear to provide a product or service with the aim of making a profit. Enterprise systems support organizational structures that were not previously possible to create a more disciplined organizational culture. An Enterprise System is a technology platform that can unify all information from various parts into one (single) information logically, so that the Enterprise (company/organization) can get the information it needs easily. The definition of HRM is a method designed to manage the resources (labor) in the company. The system was created to maximize each individual effectively, so that common goals can be achieved. Human Resource Management (HRM) according to Dessler (2006) is a policy and practice of determining aspects of human or human resources in a management position in the process of obtaining, training, assessing and compensating employees, and paying attention to their work relationships, health, safety and justice issues. Ivancevich (2007) stated that HRM is specifically filled with programs concerned with people - employees who are carried out in organizational functions that most effectively facilitate the use of employees to achieve organizational and individual goals.

\section{Research Methods}

\subsection{Research subject}

This study took 64 subjects from 2 fertilizer companies which are focused on the trading, distribution and logistics of fertilizer from producer to its trading networks and customers. The study was conducted with a non-probability sampling method through a quota sampling approach. The research subjects were selected by considering the number that was considered representative enough to represent the entire population of the company. All research subjects used as sampling in this study were employees with a service period of more than 7 years, and permanent employees, and had attended several human resource development trainings conducted by fertilizer companies, namely CV. Novie Agro Industri, and PT. Kusuma Dipa Nugraha.

\section{2. $\quad$ Variable Measurement}

The study used two main constructs of enterprise HRM as independent variable (X), and competitive advantage as dependent one $(\mathrm{Y})$ with some indicators for each construct. In this study, the indicators of enterprise human resources management (e-HRM) are measured through 8 indicators. First, selection and recruitment (X1), is the process of finding and attracting employee candidates to meet organizational needs and the process of selecting existing candidates to be matched with needs, through various scientific methods formulated in a test in a computer program. Second, training and development (X2), is a learning process that involves acquiring skills, concepts, regulations, or attitudes to improve work performance and preparing individuals to assume different or higher responsibilities in companies, organizations, institutions or educational institutions, in an effort to improve and enhance knowledge, abilities, attitudes and personality traits. Third, compensation and benefits (X3), as a company giving in both financial and non-financial forms as remuneration to employees for their time, energy, expertise and knowledge that has been given to the company, as well as gifts other than salaries, which are non-cash in nature and are intended for support the welfare of individuals and families of employees. Fourth, performance management (X4), is a strategic and integrated approach to achieving sustainable success in the organization. The strategy is to improve employee performance and develop team capabilities (Riswanto et al., 2019b; Riswanto et al., 2019a; Riswanto et al., 2020; Soetjipto et al., 2020). 
Fifth, career planning (X5), is a process where individuals can identify and take steps to achieve their career goals. Through career planning, each individual evaluates his or her own abilities and interests, considers alternative career opportunities, sets career goals, and plans practical development activities. Sixth, employee relations (X6), namely the existence of reciprocal internal communication between superiors and subordinates as well as parallel to a special field of communication, namely the extent to which an employee has the ability to manage internal relations and informal communication with the potential community as company colleagues (Susilo et al., 2019). Seventh, separation (X7), is the act of breaking the work relationship between employees and the company, by considering various measurable aspects in one data system and documented, which each employee can directly see his own competence and performance. Eighth, information system (X8), which is a system that provides information for management in making decisions and also for running company operations, and the system is a combination of people, information technology and organized procedures (Gaffar et al., 2019). For competitive advantage (Y) in supply chain excellence, there are five indicators that form competitive advantage. First, strategy (Y1), namely the company's ability to build a generic business planning framework based on two sources of supply chain excellence, namely low cost and differentiation. Second, cost leadership (Y2), is a generic strategy. This strategy is carried out by producing goods at a lower cost with relatively the same quality compared to its competitors. To be able to carry out this strategy, companies need to have higher economies of scale or have an advantage in productivity. Third, product differentiation (Y3), is the process of differentiating a product or service to make it more attractive to a particular target market. This distinction is made both to competitors' products and to other products of the product manufacturers themselves. This can be done by differentiating a little or a lot on the quality of the ingredients and the benefits of the product, as well as the packaging (Riswanto et al., 2019b). Fourth, focused differentiation (Y4), namely the ability of employees to build competitive advantage in a narrower market segment. This type of strategy is aimed at serving the needs of consumers who are relatively small in number and in making decisions to buy is relatively unaffected by price, for example meeting the needs of fertilizers for hydroponic plant lovers in urban areas, flower breeding, and so on. Finally, fifth, partnership (Y5), which is an agreement entered into by an employee with other business actors or social organizations or individuals to run a business jointly with the aim of obtaining profits and sharing the benefits obtained together. For example, with farmer groups, gardening community groups, and so on.

\subsection{Data Retrieval Technique}

The data collection process was carried out using survey techniques, and data were collected through a research questionnaire arranged in a Turnstone scale model. According to Andrich (1978) the turnstone scale is structured so that respondents choose an approved statement from several statements that present different views.

\subsection{Data analysis}

Data processing techniques using the SEM method based on Partial Least Square (PLS) require 2 stages to assess the Fit Model of a research model (Ghozali, 2016) by assessing the Outer Models and evaluating reliability and Average Variance Extracted (AVE).

\section{Results}

\subsection{Assessing the Outer Models of Measurement Model)}

There are three criteria for using data analysis techniques with Smart PLS to assess the outer model, namely Convergent Validity. Convergent validity of the measurement model with a reflexive indicator is assessed based on the correlation between the item score/component score estimated by Software PLS. An individual reflexive measure is said to be high if it correlates more than 0.70 with the measured construct. However, according to Ghozali (2016) for the initial stage of research developing a loading value measurement scale of 0.5 to 0.6 is considered sufficient.

Table 1

Instrument Validity Testing

\begin{tabular}{lcc}
\hline & Outer Weight & Outer Loading \\
\hline X1 & 0.137 & 0.703 \\
X2 & 0.190 & 0.863 \\
X3 & 0.194 & 0.892 \\
X4 & 0.196 & 0.908 \\
X5 & 0.190 & 0.877 \\
X6 & 0.196 & 0.871 \\
X7 & 0.187 & 0.555 \\
X8 & 0.104 & 0.084 \\
Y1 & -0.018 & 0.885 \\
Y2 & 0.220 & 0.904 \\
Y3 & 0.227 & 0.910 \\
Y4 & 0.231 & 0.884 \\
Y5 & 0.222 & 0.868 \\
\end{tabular}




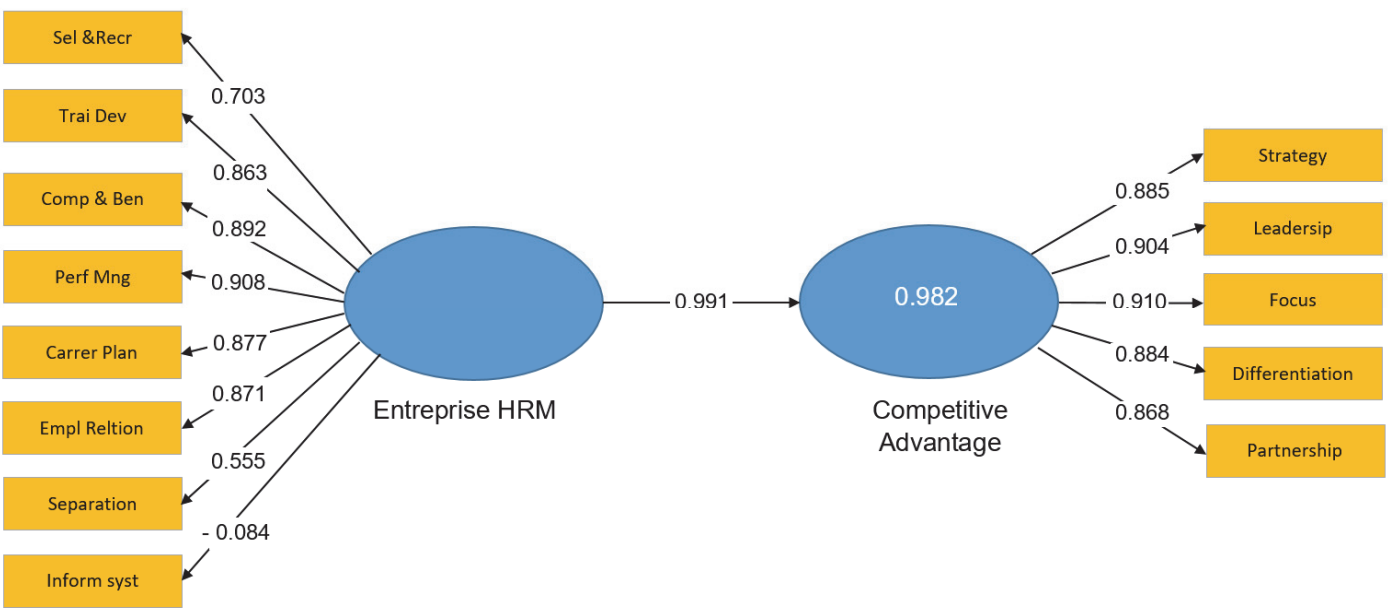

Fig. 2. Testing the Model Construct

\subsection{Evaluating Reliability and Average Variance Extracted (AVE)}

The validity and reliability criteria can also be seen from the reliability value of a construct and the Average Variance Extracted (AVE) value of each construct. The construct is said to have high reliability if the value is 0.70 and the AVE is above 0.50 . Table 2 presents the Composite Reliability and AVE values for all variables.

Table 2

Reliability Evaluation

\begin{tabular}{ccccc}
\hline & Cronbach's Alpha & Rho-A & Composite Reliability & AVE \\
\hline X & 0.863 & 0.935 & 0.904 & 0.558 \\
Y & 0.935 & 0.935 & 0.950 & 0.793 \\
\hline
\end{tabular}

Table 2 shows that all constructs meet the criteria for being reliable. This is indicated by the composite reliability value above 0.70 and AVE above 0.50 as the recommended criteria.

\subsection{Inner Models Testing}

The inner model test or structural model is carried out to see the relationship between the constructs, the significance value and the R-square of the research model. The structural model was evaluated using the R-square for the dependent construct of the $t$ test and the significance of the structural path parameter coefficients.

\section{Table 3}

Testing of Inner Models

\begin{tabular}{cccc}
\hline & Path Coefficient & $\mathbf{R}^{2}$ & $\mathbf{F}^{\mathbf{2}}$ \\
\hline Matrix & 0.991 & 0.982 & 55.353 \\
\hline
\end{tabular}

In assessing the model with PLS, it starts by looking at the R-square for each latent dependent variable. The $\mathrm{R}^{2}$ value is 0.982 which indicates that $98.2 \%$ of the company's superiority is influenced by the application of human resources management (HRM) standards with all indicators in it.

\subsection{Goodness of Fit}

The goodness of fit test (model feasibility test) was carried out to measure the accuracy of the sample regression function in estimating the actual value statistically (Ghozali, 2016). The results of the structural model test are shown in Fig. 3. 


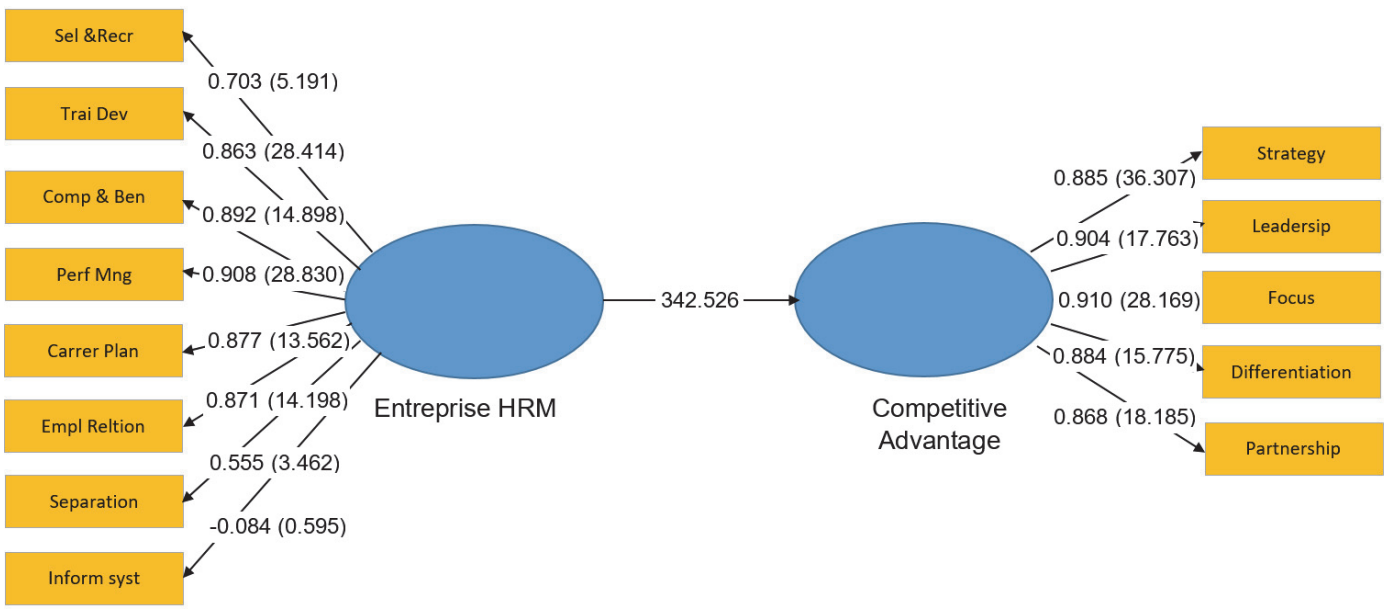

Fig. 3. Goodness of Fit Test

Table 4

Goodness of Fit (GoF) test summary

\begin{tabular}{ccc}
\hline & Saturated Model & Estimation Model \\
\hline SRMR & 0.083 & 0.083 \\
d_ULS & 0.633 & 0.633 \\
d_G & $\mathrm{n} / \mathrm{a}$ & $\mathrm{n} / \mathrm{a}$ \\
Chi-Square & $\infty$ & $\infty$ \\
NFI & $\mathrm{n} / \mathrm{a}$ & $\mathrm{n} / \mathrm{a}$ \\
\hline
\end{tabular}

GoF values ranged from 0 to 1 with the interpretation of the values: 0.1 (small GoF), 0.25 (moderate GoF), and 0.36 (large GoF). The NFI value is $>$ standard ( 0.3 but not used), and the SRMR value = model estimate $(0.163)$, which explains that the variance of the analysis model has been met or Fit. A model that meets the GOF measures described above is a good model for data. In principle, the more size criteria the model meets, the model is suitable for the data or sample we have. Because in principle SEM tests a theory that is modeled on our sample data, it is necessary to be careful and careful in determining the conclusions of the model obtained based on the GOF criteria.

\subsection{Hypothesis Testing}

In testing the hypothesis, the significance of the estimated parameters (p-value) provides very useful information about the relationship between the research variables. The basis used in testing the hypothesis is the value contained in the output result for inner weight. Table 5 shows the estimated output for structural model testing as a proving hypothesis analysis.

Table 5

Summary of Hypothesis Testing

\begin{tabular}{|c|c|c|c|c|c|}
\hline Relationship & Org & Mean & SD & T-test & p-value \\
\hline $\mathrm{HRM} \rightarrow \mathrm{CA}$ & 0.991 & 0.991 & 0.003 & 352.08 & 0.000 \\
\hline $\mathrm{SR} \leftarrow \mathrm{HRM}$ & 0.703 & 0,697 & 0.136 & 5.185 & 0.000 \\
\hline $\mathrm{TD} \leftarrow \mathrm{HRM}$ & 0.863 & 0.865 & 0.031 & 27.823 & 0.000 \\
\hline $\mathrm{CB} \leftarrow \mathrm{HRM}$ & 0.892 & 0.887 & 0.061 & 14.705 & 0.000 \\
\hline $\mathrm{PM} \leftarrow \mathrm{HRM}$ & 0.908 & 0.908 & 0.031 & 28.830 & 0.000 \\
\hline $\mathrm{CP} \leftarrow \mathrm{HRM}$ & 0.877 & 0.873 & 0.065 & 13.562 & 0.000 \\
\hline $\mathrm{ER} \leftarrow \mathrm{HRM}$ & 0.871 & 0.867 & 0.051 & 17.107 & 0.000 \\
\hline $\mathrm{SP} \leftarrow \mathrm{HRM}$ & 0.555 & 0.555 & 0.164 & 3.395 & 0.001 \\
\hline IS $\leftarrow$ HRM & -0.084 & -0.075 & 0.142 & 0.591 & 0.555 \\
\hline $\mathrm{ST} \leftarrow \mathrm{CA}$ & 0.885 & 0.888 & 0.024 & 36.307 & 0.000 \\
\hline $\mathrm{LD} \leftarrow \mathrm{CA}$ & 0.904 & 0.899 & 0.051 & 17.763 & 0.000 \\
\hline $\mathrm{FC} \leftarrow \mathrm{CA}$ & 0.910 & 0.909 & 0.032 & 28.169 & 0.000 \\
\hline $\mathrm{DF} \leftarrow \mathrm{CA}$ & 0.884 & 0.878 & 0.056 & 15.775 & 0.000 \\
\hline $\mathrm{PT} \leftarrow \mathrm{CA}$ & 0.868 & 0.865 & 0.048 & 18.185 & 0.000 \\
\hline
\end{tabular}

$\mathrm{HRM}=$ enterprise human resource management; $\mathrm{CA}=$ competitive advantage; $\mathrm{SR}=$ selection and recruitment; $\mathrm{TD}=$ training and development; $\mathrm{CB}=$ compensation and benefit; $\mathrm{PM}=$ performance management; $\mathrm{CP}=$ career planning; $\mathrm{ER}=$ employee retention; $\mathrm{SP}=$ separation; $\mathrm{IS}=$ information system; $\mathrm{ST}=$ strategy; LD=leadership; FC= focus; DF; differentiation; $\mathrm{PT}=$ partnership 
Testing analysis through partial least square (PLS) is carried out through a simulation of the modeling of the relationship between variables to determine the structure and fit between the observed variables and the predicted variables (independent variable). In this case the bootstrap method is carried out on the sample. Bootstrapping testing is also intended to minimize the problem of abnormal research data. The test results with bootstrapping from the PLS analysis showed a probability of $0.000(\mathrm{p}<0.05)$, which means that the application of enterprise HRM has an effect on company excellence in supply chain excellence in providing the product always available in the market with affordable prices. The findings denoted the importance of HRM management in increasing the supply chain excellence of company by emphasizing on the strategy, leadership, focus, differentiation and partnership. The results also highlighted the crucial role of information management to support the supply chain advantage in corporate business (Anggraeni, 2020).

\section{Discussion}

The results of the structural equation model (SEM) analysis show that the hypothesis test shows a probability value of 0.000 $(<5 \%)$, which means that the application of enterprise human resource management (HRM) is able to increase competitive advantage of supply chain of fertilizer trading companies at PT. Kusuma Dipa Nugraha and CV. Novie Agro Industry. The results of the analysis also show the structure that constructs each variable. Performance management indicators (28.830) and training and development (27.823), have the highest partial scores that provide support for the application of enterprise HRM. Then the employee relation indicators (17.107), compensation and benefits (14.705), as well as the career planning indicators (13.562) were able to provide quite large support for the HRM enterprise variable construct in the fertilizer company PT. Kusuma Dipa Nugraha. Indicators of selection and recruitment and separation or termination of employment have the smallest contribution to the enterprise HRM variable construct, while the information system indicator has a probability of more than $5 \%$, which means that it cannot contribute to the enterprise HRM variable related to internal HR management. The acceptance of the hypothesis which states that the application of enterprise HRM as an increase in company excellence supports the research conducted by Purnama and Nawangsari (2019), and the research conducted by Ehnert et al. (2016), which explains that the application of HRM in various customized model constructs with the needs of each company, it is able to develop superior potential and the company's ability to face increasingly fierce competition. Likewise, Nawangsari \& Sutawidjaya (2019) also provides the same view that HRM implementation adapted to various modes such as technological sophistication, environmental orientation, the potential of media networks and computer software as a business management support system is very relevant in increasing the company's ability to improve competitiveness and competitive excellence. Likewise, what was done by the organizations examined in this study, in the face of various competition in the production, supply chain and sales of fertilizers which are dominated by SOE companies, and government policies related to subsidies and regulation of production and distribution volumes have encouraged the two companies to increase the company's superiority in seizing the market for their products. For this reason, the most important aspect in a company gets top priority, namely employees or HR, which are the main company assets. The implementation of enterprise HRM at Kusuma Dipa Nugraha and Novie Agro Industri has entrusted its partners and several business entities in an integrated supply chain to distribute fertilizer to their distributors and retailers who have experience in various sales lines on a large enough scale to support the implementation of company information systems. The application of this enterprise HRM for all employees which includes modules for employee presentation, job performance, finance (related to compensation and benefits, as well as payroll systems), controlling, distribution, production planning, material management and project systems. Even though the system and technology used are not optimal and less optimal, or there are still some HRM applications carried out with conventional models, the impact on efforts to increase company superiority in facing competition is quite good and effective.

\section{Conclusion}

The results of this study prove that the application of enterprise Human Resources Management (HRM) is able to increase the company's supply chain excellence in facing competition. Enterprise HRM in this study is constructed by performance management, training and development, employee relations, compensation and benefits, as well as career planning which are classified as contributing to enterprise HRM implemented at the organizations examined in this study. Meanwhile, selection and recruitment and separation or termination of employment still do not provide optimal contributions, in the application of enterprise HRM and information systems utilizing internet technology are still unable to show their contribution in increasing the supply chain advantage. Practical contributions can be seen from the results of observations in the two companies, that the enterprise HRM application model in the fertilizer company still implements a company information management system to support supply chain management by employees of the IT division, and often encounters various problems related to servers and networks, and the entire system that utilizes internet technology has not been integrated for better business processes. The organizations examined in this study still needs accurate data sources to maintain communication channels at the same time with employees in the field, as well as with customers, or work relations such as distributors and retailers. Theoretically, in terms of the effectiveness of HR contribution towards the achievement of company excellence, it is also known that the applied enterprise HRM still needs to determine the direction of the company's HRM strategy. Therefore, the development of measurement tools in enterprise application in HRM or HR management is important so that HR contributions are measured more accurately, especially their contribution to company supply chain excellence in facing competition to distribute logistics and products to the market with affordable prices. 


\section{References}

Ali, A., Abrar, M., \& Haider, J. (2012). Impact of motivation on the working performance of employees-A case study of Pakistan. Asian Journal of Research in Business Economics and Management, 2(7), 328-340.

Andrich, D. (1978). Relationships between the Thurstone and Rasch approaches to item scaling. Applied Psychological Measurement, 2(3), 451-462.

Anggraeni, A. I. (2020). Executive Role in the Use of Information Technology in Public Organisations. Arthatama, 4(1).

Day, G. S., \& Wensley, R. (1988). Assessing advantage: a framework for diagnosing competitive superiority. Journal of marketing, 52(2), 1-20.

Dessler, G. (2006). Human Resource Management [Indonesian]. Jakarta: Penerbit Indeks.

Ehnert, I., Parsa, S., Roper, I., Wagner, M., \& Muller-Camen, M. (2016). Reporting on sustainability and HRM: A comparative study of sustainability reporting practices by the world's largest companies. The International Journal of Human Resource Management, 27(1), 88-108.

Fernaldi, R. (2016). Perumusan Added Value Dalam Konsep Bisnis Coffeein Melalui Pendekatan Blue Ocean Strategy. Performa: Jurnal Manajemen dan Start-Up Bisnis, 1(1).

Gaffar, V., Ridwanudin, O., Trinugraha, B., \& Riswanto, A. (2019). The influence of website navigational design on improving tourism performance: Empirical studies on sport tourism providers in Indonesia. Research in World Economy, 10(3). 408-418.

Ghozali, I. (2011). Multivariate Analysis Applications with IBM and SPSS Programs [Indonesian]. Semarang: BP Universitas Diponegoro.

Herman, H. (2018). Strategi Meningkatkan Keunggulan Bersaing Melalui Kualitas Pelayanan Pada PT Putra Usaha Mandiri Kota Batam. Jurnal Akuntansi Barelang, 3(1), 57-63.

Ivancevich, J. M. (2007). Human Resource Management. New York: McGrraw Hill Companies.

Monk, E., \& Wagner, B. (2012). Concepts in enterprise resource planning. Cengage Learning.

Mughal, M. R., (2019). Impact of green supply chain management practices on performance of manufacturing companies in Jordan: A moderating role of supply chain traceability. Arthatama, 3(2).

Nawangsari, L. C., \& Sutawidjaya, A. H. (2019, May). How the Green Human Resources Management (GHRM) Process $\mathrm{Can} \mathrm{Be}$ Adopted for the Organization Business?. In $1^{\text {st }}$ International Conference on Economics, Business, Entrepreneurship, and Finance (ICEBEF 2018). Atlantis Press.

Pepall, L., Richards, D. J., \& Norman, G. (2005). Industrial organization: Contemporary theory and practice, 3rd. Mason, OH: South-Western.

Porter, M. E. (1980). Competitive Strategy: Techniques for Analyzing Industries and Competitors. New York: Free Press.

Porter, M. E. (1985) The value chain and competitive advantage. Competitive advantage: Creating and sustaining superior performance. New York: Free Press.

Porter, M. E. (1997). Competitive strategy. Measuring Business Excellence, 1(2), 12-17.

Purnama, N.D., \& Nawangsari, L.C (2019). Pengaruh green human resource management terhadap sustainability business: Pendekatan Konsep. Prosiding Seminar Nasional Peningkatan Mutu Perguruan Tinggi. Jakarta: Universitas Mercu Buana

Rainer, R. K., \& Cegielski, C. G. (2012). Introduction to Information Systems, International Student Vers. Hoboken: John Wiley \& Sons.

Riswanto, A., Hurriyati, R., Wibowo, L. A., \& Gaffar, V. (2019a). Effect of market orientation on business performance in MSMEs as mediating by dinamic marketing capabilities. Calitatea, 20(172), 78-83.

Riswanto, A., Hurriyati, R., Wibowo, L. A., \& Gaffar, V. (2019b). Empirical assessment of the role of product innovation in dynamic marketing capabilities and company performance. Quality-Access to Success, 20(173).

Riswanto, A., Rasto, R., Hendrayati, H., Saparudin, M., Abidin, A., \& Eka, A. (2020). The role of innovativeness-based market orientation on marketing performance of small and medium-sized enterprises in a developing country. Management Science Letters, 10(9), 1947-1952.

Soetjipto, N., Susilo, D. E., \& Riswanto, A. (2020). Supply chain strategies in mediating the effect of knowledge management on business performance. Humanities \& Social Sciences Reviews, 8(1), 448-455.

Susilo, D. E., Soetjipto, N., Triwulan, A., Djuwitawati, Ratnaningtyas., Riswanto, A., Wasis, W., \& Jaya, F. P. (2019). The Effect of rmployee commitment, culture, and leadership style on good governance performance of Jombang district government. Revista Espacios, 40(27).

Wibowo, L., Widjajanta, B., Fadillah, A., Riswanto, A., Aprianti, V., Widjaja, Y., ... \& Romi, M. (2020). Supply chain analysis of hedonic shopping value on behavioral intention creation of multinational footwear company. Uncertain Supply Chain Management, 8(4), 745-752.

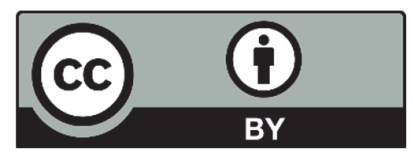

(C) 2021 by the authors; licensee Growing Science, Canada. This is an open access article distributed under the terms and conditions of the Creative Commons Attribution (CC-BY) license (http://creativecommons.org/licenses/by/4.0/). 